\title{
Conservatorship of Roulet and Cramer $v$. Tyars: Inconsistency in Involuntary Civil Commitment Protections
}

Conservatorship of Roulet ${ }^{1}$ held that proof beyond a reasonable doubt is a required safeguard which must be applied before a conservatorship can be estabhished under the Lanterman-Petris-Short Act's (LPS Act) grave disability provisions. ${ }^{2}$ Chief Justice Bird based her majority opinion on the consequences of an erroneous decision on the individual, an approach developed im earlier United States Supreme Court and California Supreme Court cases.

Cramer v. Tyars ${ }^{3}$ held that a defendant in proceedings to have him involuntarily committed as a mentally retarded person could not invoke the privilege not to be called as a witness. Justice Richardson based his majority opinion on the "civil character" of the proceedings, as evidenced by the relevant statutes. In this case, decided two weeks prior to Roulet, the court refused to extend greater due process rights to a civil commitment proceeding.

After outlining the facts in each case, this Note will trace the development of the reasonable doubt standard and the testinionial privilege in involuntary civil commitment. The Note will then analyze the opinions, first examining the reasoning behind Chief Justice Bird's determination that the reasonable doubt standard is appropriate im grave disability proceedings. The Note will argue that the majority's reasoning is more coinpelling than that of the dissent, and will expand on Chief Justice Bird's reasoning to demonstrate that the result in Roulet is correct. Second, it will explore the Cramer majority's holding that

1. 23 Cal. 3d 219, 590 P.2d 1, 152 Cal. Rptr. 425 (1979) (Bird, C.J.) (4-3 decision).

2. CAL. WELF. \& INST. CODE $§ \S 5350-5371$. Unless otherwise specified, all statutory references herein are to the Welfare and Institutions Code.

Civil commitments under $\S \S 5350$ and 5361 last for one year and are therefore deened to be long-term. For a discussion of safeguards under short-term civil commitunent, see Note, "We're Only Trying to Help": The Burden and Standard of Proof in Short-Term Civil Commitment, 31 STAN. L. REv. 425 (1979).

The LPS Act encoinpasses $\S \S 5000-5401$ of the Welfare and Institutions Code. The Act provides for the involuntary confinement and treatment of persons who as a result of a mental disorder are dangerous to themselves or others, or who are gravely disabled. When first passed in 1967, the LPS Act was hailed as a major advancement in the rights of the mentally ill. See Comment, California's New Mental Commitment Legislation: Is It Legally Sufficient?, 6 CAL. W.L. Rev. 146 (1969). With the passage of time the Act has come under criticism. See note 73 infra; Morris, Conservatorship for the "Gravely Disabled": California's Nondeclaration of Nonindependence, 15 SAN Diego L. Rev. 225 (1978).

3. 23 Cal. 3d 131, 588 P.2d 793, 151 Cal. Rptr. 653 (1979) (Richardson, J.) (5-2 decision). 
the testimonial privilege does not extend to involuntary civil commitinent proceedings.

The conflict in the reasoning of Roulet and Cramer, and the potential inequity which could result, will be discussed. The Note will resolve the conflict by showing that the reasoning used in Roulet, and not that used in Cramer, should have determined whether the testimonial privilege was extended to inental retardation proceedings. Lastly, the Note will suggest a course which the California Supreme Court should follow to resolve the conflict it has created and to adequately protect persons facing involuntary civil commitment.

\section{Statement of the CASes}

\section{A. Conservatorship of Roulet}

In 1974, Mary Roulet was placed under the conservatorship of the Public Guardian of the County of Santa Barbara. Pursuant to the conservator's instructions, Roulet was placed in Camarillo State Hospital. ${ }^{4}$

Toward the end of the original one-year conservatorship, the Public Guardian petitioned to reestablish the conservatorship for an additional year. ${ }^{5}$ Roulet demanded a jury trial on the issue of whether she was gravely disabled due to a mental disorder. ${ }^{6}$ At trial, the judge refused Roulet's request that the jury be instructed that the conservatorship could not be reestablished unless the jury agreed beyond a reasonable doubt that Roulet was gravely disabled. ${ }^{7}$ Instead, the jury was instructed that they need only believe by a preponderance of the evidence that Roulet was gravely disabled. The jury found Roulet gravely disabled. The trial court reestablished the conservatorship, and granted the conservator wide poiwers. ${ }^{8}$

4. 23 Cal. 3d at 222, 590 P.2d at 2, 152 Cal. Rptr. at 426.

5. Respondent Public Guardian's petition was under $\$ \S 5350$ and 5361.

6. Appellant's demand was under $\$ 5350$ (d).

7. The three traditional standards of proof are (1) evidence beyond a reasonable doubt, (2) clear and convincing evidence, and (3) preponderance of the evidence. The differing standards represent "an attempt to instruct the fact finder concerning the degree of confidence our society thinks he should have in the correctness of factual conclusions for a particular type of adjudication." In re Winship, 397 U.S. 358, 370 (1970) (Harlan, J., concurring). The standard of proof also represents the "value society places on individual liberty." Addington v. Texas, 441 U.S. 418, 425 (1979).

Proof beyond a reasonable doubt, the strictest standard, has traditionally been reserved for the criminal system. The least strict standard, preponderance of the evidence, has been used in typical civil adjudications. The intermediate standard, clear and convincing evidence, has been used in civil adjudications where one party's interests are held to be stronger than is usual in civil matters. In recent years, the importance of the civil or criminal label in determining the appropriate standard has lessened. See notes 19-41 and accompanying text infra.

8. The trial court granted the conservator the power to institutionalize Roulet and require 
Roulet appealed on the issue of the standard of proof for finding grave disability. ${ }^{9}$ The court of appeal reversed the order establishing the conservatorship, unanimously holding that the reasonable doubt standard was required. The California Supreme Court affirmed. ${ }^{10}$

Chief Justice Bird, writing for the majority, held that im grave disability proceedings the due process clause of the California Constitution $^{11}$ requires proof beyond a reasonable doubt. The Chief Justice rejected reliance on the proceeding's civil label, which traditionally would have led to the use of the preponderance of evidence standard. Instead, she focused on the actual consequences to the individual of a finding of grave disability. She concluded that the severity of those consequences meant that the greatest protection should be afforded. ${ }^{12}$

In a concurring and dissenting opinion, ${ }^{13}$ Justice Clark agreed with the majority that the use of the preponderance of the evidence standard was error. However, he disagreed that proof beyond a reasonable doubt was either required or appropriate for grave disability proceedings. Instead, Justice Clark believed the standard should be "clear and convincing evidence." 14

\section{B. Cramer v. Tyars}

The District Attorney of San Bernardino County filed a petition

her to receive treatment related specifically to her grave disability. The court also ordered that Roulet lose her privilege to possess a driver's license and her right to enter into contracts without the consent of the conservator. See $\S \S 5357$ and 5358. $23 \mathrm{Cal} .3 \mathrm{~d}$ at 222, 590 P.2d at 2, $152 \mathrm{Cal}$. Rptr. at 426.

9. Roulet also appealed on the issue of whether an unanimous jury verdict is required before she can be adjudged gravely disabled. The trial court refused an instruction requiring unanimous agreenent by the jury and instead instructed the jury that only nine of the twelve jurors inust agree in order to reach a verdict. The Cahfornia Supreme Court agreed with Roulet on the jury question and held that LPS Act proceedings require an unaniunous jury. The court held that "jury unanimity and the standard of proof beyond a reasonable doubt are slices of the same due process pie." $23 \mathrm{Cal} .3 \mathrm{~d}$ at $231,590 \mathrm{P} .2 \mathrm{~d}$ at $8,152 \mathrm{Cal}$. Rptr. at 432 . The court also concluded that Roulet is entitled to an unanimous jury verdict for the same reasons as those which entitle her to the standard of proof beyond a reasonable doubt. Id.

This Note will focus its discussion solely on the reasonable doubt standard.

10. The court originally heard the Roulet case in 1978. Justice Clark wrote the 4-3 majority opinion. In an opinion essentially the same as his dissent in the rehearing decision, Justice Clark held that "clear and convincing evidence" is the strictest standard required by the California Constitution. 143 Cal. Rptr. 893 (1978).

A petition for rehearing was granted. Justice Newman, who had coine onto the court between the original hearing and the rehearing, sided with the original dissenters to make up a ncw majority. Justices Tobriner, Mosk, and Newınan concurred in Chief Justice Bird's majority opinion on the rehearing.

11. CAL. Const. art. I, \& 7, subd. (a).

12. 23 Cal. $3 d$ at 223-25, 590 P.2d at 2-4, 152 Cal. Rptr. at 427-28.

13. Justices Richardson and Manuel concurred in Justice Clark's concurring and dissenting opinion.

14. 23 Cal. 3 d at 239,590 P.2d at 13,152 Cal. Rptr. at 437. 
for the commitment of appellant Tyars as a mentally retarded person. ${ }^{15}$ At the hearing to determine whether appellant was mentally retarded, appellant was called as a witness pursuant to Evidence Code section 776 which allows for the examination of an adverse party in a civil action. At that time, appellant's attorney objected to appellant being called as a witness.

The case came to the California Supreme Court on, inter alia, the issue of whether a defendant to a petition for involuntary commitment as a mentally retarded person had a constitutional testimonial privilege not to be called as a witness. ${ }^{16}$

Justice Richardson, writing for the majority, recognized the witness' right im any proceeding, civil or criminal, not to answer incriminating questions. But he noted that the distinct right to refuse to take the stand at all traditionally could only be invoked by a defendant in a criminal case. Justice Richardson held that because the commitment proceedings were civil, as evidenced by various features of the relevant statutes, the defendant could not refuse to testify. ${ }^{17}$

Chief Justice Bird wrote a vigorous dissent, which was to become the basis for her majority opinion in Roulet. She reasoned that the consequences of a finding of mental retardation are so similar to both the consequences of criminal imprisonment and the consequences of confinement in those civil cases where the criminal protections have been extended that the same testimonial privilege should extend to each. ${ }^{18}$

II

The Development of the Reasonable Doubt Standard and the Testimonial Privilege in INVOLUNTARY CIVIL COMMITMENT

Until 1975 the California Supreme Court looked to "civil" or "criminal" labels to determine the appropriate procedural protections to be used in actions affecting the rights of individuals. Involuntary commitment proceedings were deemed civil in nature, and traditional civil procedures-such as the preponderance of the evidence standard

15. The District Attorney's petition was under $\S 6502$.

16. The issue of a witness' right not to answer incriminating questions was also raised. At the commitment proceedings the judge required Cramer to answer all questions. In the course of answering certain questions he mcriminated himself. The majority held that the judge's violation of Cramer's fifth amendinent rights was harmless error. 23 Cal. 3d at 138-39, 588 P.2d at 797, 151 Cal. Rptr. at 657-58. The dissent strongly disagreed. Id. at 149, 588 P.2d at 804, 151 Cal. Rptr. at 664.

17. Id. at $137-38,588$ P.2d at $796-97,151$ Cal. Rptr. at $656-57$.

18. Id. at $148-49,588$ P.2d at 803-04, 151 Cal. Rptr. at 663-64. Justice Newman also dissented in a separate opinion. Id. at 150, 588 P.2d at 805, 151 Cal. Rptr. at 665. 
of proof, and the absence of the absolute testimonial privilege-were applied. ${ }^{19}$

The court changed its view in People v. Burnick ${ }^{20}$ and People v. Feagley. ${ }^{21}$ Both cases involved defendants who had been found guilty of misdeineanors, ${ }^{22}$ and who, in subsequent hearings, had been adjudged to be inentally disordered sex offenders (MDSO). ${ }^{23}$

Justice Mosk, writing for the inajority in both cases, rejected the importance of the "civil" label. ${ }^{24}$ Instead, he einbraced the analysis developed by the United States Supreme Court in Specht v. Patterson, ${ }^{25}$ In re Gault, ${ }^{26}$ and In re Winship. ${ }^{27}$

In those cases, the United States Supreme Court discounted the importance of civil/criminal labels, and instead focused on the individual's potential loss of hiberty and stigmatization resulting from the nominally civil adjudication. The constitutional safeguards accorded

19. The label approach represents jndicial deference to a legislative determination of the appropriate standard of due process protection to incorporate into a proceeding. See, e.g., People v. Moore, 69 Cal. 2d 674, 446 P.2d 800, 72 Cal. Rptr. 800 (1968); People v. Valdez, 260 Cal. App. 2d 895, 67 Cal. Rptr. 583 (2nd Dist. 1968). Both Moore and Valdez involved narcotic addiction proceedings. The Valdez court anticipated the use of the "actual consequences" approach when it said, "[a] situation may well arise where [the civil] characterization inay break down in the face of the reality of the addict's involuntary confinement." Id. at 904, 67 Cal. Rptr. at 589 (citation omitted). But see Cramer v. Tyars, 23 Cal. 3d 131, 588 P.2d 793, 151 Cal. Rptr. 653 (1979), and notes $91-96$ infra.

While the court exphicitly applied the civil standard of proof in pre-1975 cases such as Moore, no appellate court had dealt directly with the availability of the testimonial privilege in coinmitment proceedings. But it appears that the court would have used the same reasoning and denied the privilege.

20. 14 Cal. 3d 306, 535 P.2d 352, 121 Cal. Rptr. 488 (1975).

21. 14 Cal. 3d 338, 535 P.2d 373, 121 Cal. Rptr. 509 (1975).

22. Burnick had engaged in consensual homosexual acts with two boys aged 13 and 15 . He was found guilty of violations of CAL. PENAL CODE $\$ \S 647$ a (conduct which "annoys or molests" a person under the age of 18) and 272 (contributing to the delinqnency of a person under the age of 21 (now 18)). 14 Cal. 3d at 311 n.2, 535 P.2d at 355 n.2, 121 Cal. Rptr. at 491 n.2.

Feagley, in the course of a conversation with two eight year old girls who lived in the area where he worked, briefly stroked both girls' hair and the backs of their necks. That was the only contact between them. He was charged with a violation of CAL. PENAL CODE $\$$ 647a. This charge was dismissed when Feagley pleaded guilty to the lesser included offense of simple battery. Id. at 342-43, 535 P.2d at 375, 121 Cal. Rptr. at 511.

23. Section 6300 defines a MDSO as "any person who by reason of mental defcct, disease, or disorder, is predisposed to the commission of sexual offenses to such a degree that he is dangerous to the health and safety of others."

Section 6302 provided that when a person was convicted of any criminal offense, whether or not a sexual offense, the trial judge could certify the defendant to the superior court for a hearing on whether the person was a MDSO. A 1976 amendment to $\$ 6302$ now limits its applicability to persons found guilty of sex offenses. Ch. 1101, $\$ 2,1976 \mathrm{Cal}$. Stats. 4973.

24. Burnick, 14 Cal. 3d at 314, 535 P.2d at 357, 121 Cal. Rptr. at 493; Feagley, 14 Cal. 3d at 350, 535 P.2d at 380, $121 \mathrm{Cal}$. Rptr. at 516.

25. 386 U.S. 605 (1967).

26. 387 U.S. 1 (1967).

27. 397 U.S. 358 (1970). 
the defendant were determined by the severity of the consequences following an erroneous adverse judgment rather than by the proceedings' traditional civil characterization.

In Gault, the United States Supreine Court held that a juvenile facing criminal-like sanctions could refuse to testify under the fifth amendment privilege. ${ }^{28}$ The Court rejected the argument that the availability of the privilege should turn on the label, civil or criminal, which denominates the proceeding. The Court asserted that the availability of the privilege should turn on the "nature of the statement or admission and the exposure it invites." 29 The Court held that the interests protected by the fifth amendinent are as threatened in a juvenile proceeding as in a criminal trial. ${ }^{30}$

The Court's analysis was more fully developed in Winship, which also dealt with the safeguards to be provided juveniles in proceedings before a juvenile court. The proceedings in Winship were conducted under the New York Family Court Act, and the trial judge used the preponderance of the evidence standard in finding the juvenile culpable. $^{31}$

The Court reasoned that one function of the standard of proof is to reduce the risk of an erroneous conviction: a high standard of proof lowers the risk that an innocent defendant will be found guilty. ${ }^{32}$ The Court argued that proceedings which result in grave consequences to the defendant should have a high standard of proof in order to decrease the risk that innocent defendants will needlessly be made to suffer. ${ }^{33}$

The Court identified two key consequences of criminal proceedings: the possibility that the accused may lose his liberty upon conviction, and the certainty that he will be stiginatized by the conviction. ${ }^{34}$

28. 387 U.S. at 55. The juvenile in Gault was accused of making an obscene phone call. The Court held that it was an error when "[n]either [the minor] nor his parents were advised that he did not have to testify or make a statement . . . ." Id. at 43-44.

29. Id. at 49.

30. The Gault Court argued that the privilege against self-incrimination is necessary to assure that admissions or confessions are reasonably trustworthy, that they are not mere fruits of fear or coercion but are reliable expressions of the truth. . . . One of its purposes is to prevent the state, whether by force or by psychological domination, from overcoming the mind and will of the person under mvestigation and depriving him of the freedoun to decide whether to assist the state in securing his conviction.

387 U.S. at 47 (footnote omitted). The spectre of psychological domination would seem particularly acute in the case of the gravely disabled or mentally retarded.

The Court also noted that denymg the privilege to the juvenile might put him in danger of eventual criminal prosecution in the criminal courts. Id. at 49-50.

31. 397 U.S. at 360 . The juvenile in Winship was accused of having stolen money from a locker.

32. Id. at 363-64. The Court also noted that the reasonable doubt standard helps to engender respect and confidence in the criminal law.

33. Id.

34. Id. at 363. 
The importance of these two consequences to an innocent defendant, erroneously convicted, led the Court to conclude that a defendant in a criminal action was constitutionally entitled to a standard of proof which permits conviction only if the jury finds the defendant guilty beyond a reasonable doubt.

The Court then compared the potential consequences in a criminal trial to the possible loss of hberty and injury to reputation which may be experienced by an innocent juvenile found delinquent. The Court noted that simce a juvenile found delinquent could be incarcerated for several years, the loss of liberty is comparable in seriousness to a felony conviction. ${ }^{35}$ The Court also believed that the stigma which attaches to a juvenile delinquent is not significantly different than that which attaches to a criminal. ${ }^{36}$ The Court concluded that juveniles were entitled to the same standard of proof as that accorded criminal defendants.

In People v. Burnick, Justice Mosk applied the Winship Court's analysis to the California mentally disordered sex offender law. ${ }^{37}$ After outlining the loss of freedom ${ }^{38}$ and stigmatization ${ }^{39}$ facmg a defendant found to be a MDSO, Justice Mosk concluded that the highest standard of proof-beyond a reasonable doubt-was constitutionally required. ${ }^{40}$ In his opimion, Justice Mosk made clear that the California court would look to the actual consequences of the proceedings, rather than the legislature's label, in order to determine which due process standards are constitutionally required. ${ }^{41}$

In Conservatorship of Roulet, Chief Justice Bird apphed the Winship-Burnick analysis to the grave disability provisions of the LPS Act.

35. Id. at 365-66.

36. Id. at 367,374 .

37. 14 Cal. 3 d at 318,535 P.2d at 360,121 Cal. Rptr. at 496-97.

38. Id. at 319-20, 535 P.2d at 360-62, 121 Cal. Rptr. at 496-97.

39. Id. at 321-22, 535 P.2d at 361-62, 121 Cal. Rptr. at 497-98.

40. Id. at 322, 535 P.2d at 362, 121 Cal. Rptr. at 498.

41. Id. at 315-16, 535 P.2d at 358, 121 Cal. Rptr. at 494.

In People v. Feagley the court used the Burnick analysis to add the requirement of jury unanimity to MDSO proceedings.

Two years later, in People v. Thomas, 19 Cal. 3d 630, 566 P.2d 228, 139 Cal. Rptr. 594 (1977), the court held that in proceedings to determine if a defendant is a narcotics addict, proof beyond a reasonable doubt is required.

In Thomas, Justice Mosk, again writing for the unajority, compared the possible confinement and stigma of a narcotics addict to that of a juvenile delinquent. After finding the possible loss of liberty and stigmatization greater for a narcotics addict than for a juvenile delinquent, lie concluded that "the standard in narcotics addict conimitinent proceedimgs must be . . . proof beyond a reasonable doubt." Id. at 641,566 P.2d at 234, 139 Cal. Rptr. at 600 . The court's philosophy was stated thus: "[T] he choice of standard of proof implicates due process considerations which must be resolved by focusing not on the theoretical nature of the proceedings but rather on the actual consequences of commitment to the individual." Id. at 638,566 P.2d at 232, 139 Cal. Rptr. at 598 (empliasis added). 
After outlining the loss of liberty and the stigmatization facing a defendant erroneously found to be gravely disabled, Chief Justice Bird concluded that proof beyond a reasonable doubt was constitutionally required. ${ }^{42}$

Conservatorship of Roulet represents a new and significant application of the analysis developed in Winship and applied in Burnick. Prior to Roulet, the California Suprenue Court applied the Winship analysis, and the higher due process standards, only to those schemes which demonstrated that the legislature's intent was to protect both the subject of the proceedings from himself and other persons and property from the subject's actions. ${ }^{43}$ However, the legislature's purpose in enactimg the grave disability section of the LPS Act was solely benevolent: to provide care for those unable to satisfy their personal needs for food, clothing, and shelter. ${ }^{44}$ The Act seeks neither retribution nor protection of society. Roulet, therefore, represents an extention of the rights of those persons who come into the inental health system.

The reasoning of Roulet is challenged by the United States Supreme Court decision in Addington v. Texas. ${ }^{45}$ In that case, the Court prescribed the required standard of proof for involuntary commitment proceedings. The Court looked to the consequences of confinement, but distimguished the action from the Winship proceeding. The basis for the distmction was that, unlike the Winship situation, the Addington proceedings had no punitive purpose. The Court held that the United States Constitution requires only the standard of "clear and

42. See text accompanying notes 50-61 infra.

43. See People v. Thomas, 19 Cal. 3d 630, 566 P.2d 288, 139 Cal. Rptr. 594 (1977) (narcotic addict proceedings); People v. Feagley, 14 Cal. 3d 338, 535 P.2d 373, 121 Cal. Rptr. 509 (1975) (MDSO proceedings).

The hearing to determine MDSO or addict status only occurs after conviction of a criminal offense. Additionally, $\S 6300$ defines a MDSO as one who is "dangerous to the health and safety of others." Section 3051 provides that persons adjudged to be narcotic addicts are to be turned over to the Director of Corrections.

44. See $\S \S 5008(\mathrm{~h}), 5350,5352$. The LPS Act may have an element which taints the grave disability proceedings with an element of criminahty. Subdivision 2 to $\S 5008$ (h)-added by 1974 Cal. Stats., ch. 1511, §12-does relate grave disability to crimmal behavior. Recent commentators have identified subdivision 2 as a legislative attempt to circumvent the United States Supreme Court decision in Jackson v. Indiana, 406 U.S. 715 (1972). Jackson held that persons accused of crimimal conduct, and who are adjudged incompetent to stand trial, could not be imstitutionalized indefinitely. After a reasonable period they must either be released or committed under normal civil commitunent procedures. The commentators have criticized the imclusion of subdivision 2 in the grave disability provisions. See Morris, Conservatorships for the "Gravely Disabled": California's Nondeclaration of Nonindependence, 15 SAN DIEGo L. REv. 225 (1978); Parker, Commitment of Individuals Found Incompetent to Stand Trial: California's New Scheme, 6 PACIFIC L.J. 484 (1975).

However, both the majority and the dissenters in Roulet treated the grave disability provisions as if they were free from any tie with the criminal system.

45. 441 U.S. 418 (1979). 
convincing evidence," although states are free to adopt a higher standard. ${ }^{46}$ Although the Addington decision does not affect the status of Roulet since Roulet was based on the California Constitution, it does inandate a second look at the rationale applied in Roulet.

Moreover, the California Supreme Court's very adlierence to the Winship-Burnick "actual consequences" approach, as apphed in Roulet, is clouded by its decision in Cramer v. Tyars. ${ }^{47}$ In Cramer the court used the previously discredited "labels" approach in determining that the subject of civil commitment proceedings is required to respond to non-incriminating questions which may be used to commit him. The court in Cramer gave no reason for its return to what Chief Justice Bird in her dissent called "a node of analysis [i.e., the labels approach] which has been repeatedly rejected as a nethod of determining the safeguards which inust apply in commitment proceedings." 48 A careful analysis of these three opinions will reveal the essential soundness of the Roulet majority position.

\section{III}

\section{ANALYSIS OF THE OPINIONS}

\section{A. Roulet}

The heart of Chief Justice Bird's opinion is the belief that regardless of the admirable rehabilitative goals of the grave disability provisions, "[t]he law must still strive to make certain that only those truly unable to take care of themselves are being assigned conservators under the LPS Act and committed to inental hospitals against their will." ${ }^{39}$ The Chief Justice concluded that the only way to insure that certainty is by extending the highest standard of proof to those who are the subjects of grave disability proceedings.

The Chief Justice justified the need for such a high degree of certamty on the ground that grave consequences will befall a person who is erroneously adjudged inentally disabled. ${ }^{50}$ Following the analysis put forward in Winship and Burnick, slie focused her discussion on the loss of hiberty and injury to reputation which follow a finding of grave mental disability. The Chief Justice compared the consequences suffered by a person adjudged gravely mentally disabled with the consequences suffered by persons in otlier proceedings which require the

46. Id. at $430-33$.

47. 23 Cal. 3d 131, 588 P.2d 793, 151 Cal. Rptr. 653.

48. Id. at $143,588 \mathrm{P} .2 \mathrm{~d}$ at $800,151 \mathrm{Cal}$. Rptr. at 660 (Bird, C.J., dissenting).

49. 23 Cal. 3d at 225, 590 P.2d at 4, 152 Cal. Rptr. at 428 (einphasis added).

50. Id. at 223,590 P.2d at 3, 152 Cal. Rptr. at 427. 
reasonable doubt standard (e.g., criminal defendants, MDSO's, ${ }^{51}$ and narcotic addicts ${ }^{52}$ ). Her conclusion rested on the argument that since persons who are found to be gravely disabled suffer essentially the same loss of liberty and injury to reputation as criminals, MDSO's, and addicts, then the alleged gravely disabled person should be protected from the risk of an erroneous finding by the same high standard of proof.

As a basis for comparing the loss of hiberty suffered by one found to be gravely inentally disabled with the loss experienced by one found criminally liable, the court identified four essential features of loss of hiberty: duration, nature, and place of confinement, and additional deprivation of rights. ${ }^{53}$ Chief Justice Bird concluded that the loss suffered by the gravely disabled is equivalent to-if not greater than-the loss experienced by many criminals in each of these four areas. ${ }^{54}$ She argued that defendants in a LPS Act proceeding face potentially lifelong ${ }^{55}$ confinement $^{56} \mathrm{im}$ a state mental hospital which closely resembles a prison. ${ }^{57}$ Moreover, the gravely disabled may lose additional rights. ${ }^{58}$

The majority also asserted that a "stigma" attaches to a person found to be gravely disabled which can be as socially debilitating as the stigma of criminal conviction. ${ }^{59}$

51. See People v. Burnick, 14 Cal. 3d 306, 535 P.2d 352, 121 Cal. Rptr. 488 (1975); People v. Feagley, 14 Cal. 3d 338, 535 P.2d 373, 121 Cal. Rptr. 509 (1975).

52. See People v. Thomas, 19 Cal. 3d 630, 566 P.2d 288, 139 Cal. Rptr. 594 (1977).

53. 23 Cal. 3d at 223-28, 590 P.2d at 3-6, 152 Cal. Rptr. at 427-30.

54. Id. at 228,590 P.2d at 6, 152 Cal. Rptr. at 430 .

55. The "[t]heoretical maximum period of detention is life as successive petitions may be filed . . ." Id. at 225, 590 P.2d at 3, 152 Cal. Rptr. at 427 (citation omitted) (court's emphasis).

Moreover, the Chief Justice poimted out that once a patient is in a inental hospital, the environment of the hospital makes it increasingly easy to show that the person is ill. $I d$. at 234, 590 P.2d at 10, 152 Cal. Rptr. at 434.

56. Id. at 224,590 P.2d at 3, 152 Cal. Rptr. at 427.

57. "In Burnick, this court soberly recognized the resemblance in reality between Atascadero State Hospital and a conventional prison." Id. at 226,590 P.2d at 5, 152 Cal. Rptr. at 429. For the full description in Burnick, see 14 Cal. 3d at 306, 319-20, 535 P.2d 352, 360-61, 121 Cal. Rptr. 488, 496-97.

58. The Roulet court noted that

[a]n individual found to be "gravely disabled" may suffer numerous statutory disabilities, including possible loss of the following rights: to remain licensed to practice a profession (e.g., law (Bus. \& Prof. Code, § 6007, subd. (a)); medicine (Bus. \& Prof. Code, $\$ \S 2416,2417$ ); to continue to hold certain public offices (Gov. Code, § 1770, subd. (b)); to remain employed as a teacher (Ed. Code, $\$ \S 44932,87732$ ); to establish or maintain certain relationships (e.g., custody of children (Civ. Code, $\$ 232$, subd. (a) (6)); marriage (Civ. Code, $\S \S 4201,4506)$; to object to sterilization ( $\$ 7254)$; to refuse certain types of medical treatment ( $\$ \$ 5357$, subds. (c), (d), 5358); to possess a driver’s license (\$5357, subd. (a)); to own or possess firearms ( $\$ \S 8100,8102,8103$ ); to remain registered to vote (Elec. Code, \$ 701); and to enter into contracts (\$ 5357, subd. (b))).

23 Cal. 3d at 228, 590 P.2d at 6, 152 Cal. Rptr. at 430 .

59. The Chief Justice cited numerous cases and articles showing that an individual is stigmatized by the label "mentally ill." Id. at 229 n.7, 590 P.2d at 6-7 n.7, 152 Cal. Rptr. at $430-31$ n.7.

The Chief Justice summarized her reasoning by saying: 
Finally, the Chief Justice argued that her analysis and conclusion were entirely consistent with the Burnick, Feagley, and Thomas cases, which held that the California Constitution requires proof beyond a reasonable doubt in certain other civil commitment proceedings. ${ }^{60}$ She concluded, "Logic and law, as well as regard for the value of liberty, compel this court to follow those decisions today." 61

In his concurring and dissenting opinion, Justice Clark attacked the majority's reasoning on two grounds. ${ }^{62}$ First, he argued that the consequences of the grave disability proceedings are not as severe as the consequences of criminal trials. Second, he argued that the state's benevolent purpose in the grave disability proceedings distinguishes those proceedings from criminal trials, where the state pursues punitive and protective purposes.

Clark noted that the confinement under the statute is in a hospital rather than a prison, and is limited to one year. ${ }^{63}$ Yet following the "actual consequences" approach, it is difficult to understand how these distinctions make any real difference. Many criminal punishments are for less than a year, but the loss of liberty is still considered severe; the fact that an individual is confined in a "hospital" does not lessen the pain of the confinement. ${ }^{64}$ In addition, the subject of an MDSO proceeding or the subject of a juvenile hearing may be exposed to shortterm confinement in a facility other than a prison, but the United States and California Supreme Courts used reasoning similar to Roulet's in requiring increased procedural safeguards in those settings.

The dissent also pointed out that a committed individual is entitled to two hearings during the initial one-year period of confinement to challenge the continuation of the conservatorship. ${ }^{65}$ But the real value of this safeguard is questionable. The statute which provides for these hearings does not specify that they be full jury trials with all the attendant procedural protections. ${ }^{66}$ Moreover, in these later hearings the conservatee faces many of the same disadvantages which weighed in favor of the higher standard in the original conservatorship trial. ${ }^{67}$

A finding of grave disability is equivalent to a finding that a person is unable to feed, clothe or house himself because of a mental disorder [citation oinitted]. It is implausible that a person labelled by the state as so totally ill could go about, after his release, seeking employment, applymg to schools, or meeting old acquaintances with his reputation fully intact.

Id. at 229, 590 P.2d at 6-7, 152 Cal. Rptr. at 430-31.

60. Id. at 235,590 P.2d at 11,152 Cal. Rptr. at 435 .

61. Id.

62. Id. at 235, 590 P.2d at 11, 152 Cal. Rptr. at 435 .

63. Id. at 238, 590 P.2d at 13, 152 Cal. Rptr. at 436-37; see $\S 5361$.

64. See note 57 supra.

65. $23 \mathrm{Cal}$. $3 \mathrm{~d}$ at 238,590 P.2d at 13, $152 \mathrm{Cal}$. Rptr. at 436-37.

66. See $\S \S 5364,6000$.

67. The inajority noted "the difficulty of defining inental illness, the factfinder's deference to 
Because the conservatee is confined prior to these hearings, his ability to prepare for them is limited. The conservatee's behavior in confinement can be used to justify the claim of continued grave disability, even though a healthy individual's reaction to confinement may not be imdicative of his normal behavior. Additionally, the judges give great deference to psychiatric testimony. Lastly, the conservatee's counsel may take the paternalistic attitude frequently taken by counsel, and thus fail to really work for the conservatee's release. For these reasons the opportunity to get an early termination of the conservatorship is largely illusory.

Justice Clark also asserted that altliough a stigma may attach to one who has been committed, it is different in kind and degree from the stigma associated with a criminal conviction. A gravely disabled person, Clark believed, is far more likely to be viewed with compassion than to be viewed with the fear and mistrust which accompanies criminal conviction. ${ }^{68}$

Unfortunately, Justice Clark's idealistic vision of how society views the mentally ill is simply not borne out im reality. Persons committed as mentally ill very often suffer great stigma when they return to society. The effects of this stigma range from discrimination in employment and education to interference with social relationships. ${ }^{69}$ However the Justices may choose to characterize the stigma, it is still the consequences of the stigma which are relevant.

Justice Clark's second objection is more important and potentially more damaging that the first. By arguing that the majority's analogy to the criminal systen is invalid because of the exclusively benevolent purposes of the grave disability provisions, he is limiting the application of the Winship-Burnick analysis only to those proceedings which have punitive purposes. The statutory schenies before the court in Burnick, Feagley, and Thomas sought retribution and/or protection of society. ${ }^{70}$ The grave disability provisions seek only to provide care for those unable to satisfy their personal needs for food, clothing, and shelter. $^{71}$

Unfortunately, the validity of the benevolent-punitive purpose dis-

psychiatric testimony, and the paternalistic attitude of some appointed counsel." $23 \mathrm{Cal}$. $3 \mathrm{~d}$ at 225, 590 P.2d at 11, 152 Cal. Rptr. at 434-35.

68. Id. at 238, 590 P.2d at 13, 152 Cal. Rptr. at 436-37. Justice Clark warned that increasing the standard of proof might increase the stigma. However, this seems unlikely since stigmatization was found to result from the categorization of a person as mentally ill, not upon the legal technicalities involved in finding him to be mentally ill. See note 59 supra.

69. See Developments in the Law-Civil Commitment of the Mentally IIl, 87 HARv. L. REv. 1190, 1200-01 (1974); accord Rosenhan, On Being Sane in Insane Places, 13 SanTA Clara L. REv. 379, 385, \& authorities cited in $\mathrm{n.11}$ (1973). See also note 59 and accoinpanying text supra.

70. See note 43 supra.

71. See $\$ \$ 5008(\mathrm{~h}), 5350,5352$. 
tinction as a reason for not extending the Winship-Burnick analysis is not fully discussed in this case. Justice Clark suggested that when the state's purposes are benevolent there is less chance of abuse. ${ }^{72}$ However, there is ample evidence which suggests that abuses do exist in the present systein. ${ }^{73}$ Even if the civil coinmitinent procedures are completely free from suspicion of bad faith on the part of the state, the reasonable doubt standard nay be necessary as a safeguard against the inevitable honest mistake. Benevolence and good intentions do not ameliorate the loss of liberty and injury to reputation for an erroneously committed defendant.

A full discussion of the benevolent-punitive distmction requires an inquiry into the balance of interests served by punitive and by benevolent incarceratory scheines.

In criminal trials the state has four recognized interests: deterrence, rehabilitation, incarceration of dangerous persons, and retribution. ${ }^{74}$ Balanced against these interests are the innocent individual's goals of protecting his liberty and his reputation. A basic tenet of the criminal justice system holds that the interests of the individual are of such importance that they will be accorded the inaximuin protection of the reasonable doubt standard. ${ }^{75}$

In civil commitınent proceedings the state's interests are incarceration and rehabilitation. ${ }^{76}$ However, unlike criminal cases, where a major purpose of confineinent is to protect society, the goal in grave

72. Justice Clark said,

When the government's actions are motivated not only by benevolence towards the individual, but also by an interest in protecting others from the individual's behavior, potential abuse exists. The proceedings may be misused as a substitute for criminal prosecution, justifying the additional safeguard . . . to protect the individual against risk of error. . . . Because this interest is not present in grave disabihity proceedings, imininently dangerous and gravely disabled persons are not similarly situated.

23 Cal. 3d at 240-41, 590 P.2d at 14, 152 Cal. Rptr. at 438 (citations and footnote omitted).

73. As a recent study of a large inetropohitan community's mental health court sadly con"cluded,

Grave disablement standards dealt less with food, clothing, shelter, and finances-functioning within the community-than with functioning inside the farnily and mental health system. This suggests that considerations of individual rights and the protection of society are displaced . . . by considerations of the relief of fainily tensions and the smooth functioning of the mental health system.

Warren, Involuntary Commitment for Mental Disorder: The Application of California's LantermanPetris-Short Act, 11 LAW AND SOCIETY REv. 629, 647 (1977). Cf. Ellis, Volunteering Children: Parental Commitment of Minors to Mental Institutions, 62 CALIF. L. REv. 840 (1974) (Ellis concluded that parents often commit their children not for paternalistic reasons, but because the parents want a way out of a difficult family situation). See also Note, The Lanterman-Petris-Short Act: A Review After Ten Years, 7 GoldEN GATE L. REv. 733 (1977).

74. See In re Ballay, 482 F.2d 648, 657 (D.C. Cir. 1973).

75. See In re Winship, 397 U.S. at 364.

76. In civil commitment proceedings there is no retribution mterest since there has been no act which calls for retribution. Presumably people can not be deterred from becoining inentally ill, so there is no deterrence imterest. 
disability proceedings is to protect the individual from himself. ${ }^{77}$ Yet in civil commitment proceedings, individuals still have an interest in not being erroneously committed. Those who are gravely disabled but are too ill to realize their condition and to seek help voluntarily may be said to have an "interest" in being made a conservatee. ${ }^{78}$ Thus, the interests of the able individual are weighed agamst the interest of the gravely disabled and the interests of the state. Unlike the criminal context which weighs the individual's interests against the interest of the state, the relevant question in civil commitment proceedings is whether the harm to an individual erroneously committed outweighs the harm to the person erroneously released. Justice Clark argued that the balance weighs in favor of protecting the erroneously released person; the danger to him outside of the hospital ought to be guarded against by adopting a lower standard for committal. ${ }^{79}$

There are, however, reasons why Justice Clark's judgunent on this issue should be rejected, and the balance should weigh in favor of protecting the interests of the erroneously committed over the interests of the erroneously released. The alternatives available following an erroneous determination favor protecting the erroneously committed. As a practical matter, it may well be that one who is gravely disabled and has not been committed will receive necessary help outside of the hospital. Halfway houses, community mental health centers, and shortterm commitment procedures are possible sources of assistance to such a person. ${ }^{80}$ Thus the catastrophic harm to an erroneously released person posited by Justice Clark is by no ineans a certainty. On the other hand, the erroneously committed face a minimunı confineinent of one year. The procedures for reducing that one year confinement have al-

77. "The [LPS] Act serves to protect the person from the consequence of his own infirmity rather than to protect society from the person." 23 Cal. 3d at 237, 590 P.2d at 12, 152 Cal. Rptr. at 436 (Clark, J., concurring and dissenting).

78. To speak of the gravely disabled's interest in being committed against his will does some violence to the standard notion of interest. We do not normally speak of the criminal's imterest in being found guilty so he can be punished against his will. lt is perhaps better to subsume the gravely disabled's interest in involuntary commitment into the state's interest in confinement and rehabilitation of the gravely disabled.

79. 23 Cal. 3d at 239, 590 P.2d at 13-14, 152 Cal. Rptr. at 437 (Clark, J., concurring and dissenting). Accord, Addington v. Texas, 441 U.S. at 429.

80. See Aviram and Siegal, From Hospital to Community Care: The Change in the Mental Heallh Treatment System in California, 13 Community Mental Health J. 158 (Summer 1977).

Section 5150 provides for 72-hour detention of persons who are dangerous to themselves or others. The standard for such detention is "probable cause," as determined by a peace officer or designated members of mental health facilities.

Section 5250 provides for a 14-day "certification" period which may follow the 72-hour detention.

See generally Note, "We're Only Trying to Help": The Burden and Standard of Proof in ShortTerm Civil Commitment, 31 STAN. L. REv. 425 (1979). 
ready been shown to be inadequate. ${ }^{81}$

Justice Clark's view also ignores earlier cases involving proceedings which in large part were intended to benefit the defendants. MDSO actions, sucl as those in Burnick and Feagley, contain important reliabilitative eleinents, as does the typical juvenile proceeding represented in Gault and Winship. By using the reasonable doubt standard, these earlier actions weiglied the individual's interest in not being erroneously confined over their interest in not being erroneously released. Of course, these proceedings are arguably partly punitive. But that means that the state's interest in confinement is greater in those proceedings than in grave disability proceedings. The lesser state interest in grave disability proceedings suggests the need for greater protection against erroneous confineinent. ${ }^{82}$ Thus the benevolent-pumitive purpose distinction does not offer a convincing reason not to extend the Winship-Burnick analysis to grave disability proceedimgs.

The United States Supreme Court in Addington v. Texas ${ }^{83}$ offered two additional reasons, besides the benevolent-punitive purpose distinction, why the reasonable doubt standard might be inappropriate in civil commitment proceedimgs: the standard has historically been reserved for criminal cases, and the standard nay be too higli to permit the state to fulfill its goals in this area.

The United States Supreme Court feared that applying the reasonable doubt standard too broadly, to cases outside of the criminal system, will dilute the special moral force which that standard brings to the criminal law. ${ }^{84}$ The Court offered no evidence that sliows that sucl a dilution would occur.

It is difficult to believe that the Court considers the dilution of the reasonable doubt standard to be a realistic possibility in terms of its practical effect on juries. In the opmion, the Court candidly conceded that it is entirely unclear low well jurors understand the different standards of proof, or how these standards affect their decisions. ${ }^{85}$ Despite the Court's skepticism about the practical effect of adopting one standard over anotlier, the Court recognized and empliasized the symbolic value of the standard. "In cases involving individual riglits, whetler criminal or civil, 'tlie standard of proof at a minimuin reflects the value society places on individual liberty." "86 This argument, based on the

81. See text accompanying notes $65-67$ supra.

82. This conclusion is based on the balance approach. The argument that a lcsser state interest suggests that lesser protections are adequate is based on the idea that there would be less chance of abuse. See note 72 supra. But see note 73 and accompanying text supra.

83. 441 U.S. 418 (1979).

84. Id. at 428.

85. Id. at $424-25$.

86. Id. at 425 . 
symbolic value of the standard, surely speaks in favor of applying the reasonable doubt standard in civil commitment proceedings. If the same loss of mdividual liberty is at stake in both kinds of proceedings, then both should be accorded the sanie symbolic recognition.

The Addington Court's second argument concerns the relation between the standard of proof and the nature of the evidence presented. Given the lack of certainty and the fallibility of psychiatric diagnosis, the Court questioned whether a state could ever prove beyond a reasonable doubt that the individual is gravely disabled. ${ }^{87}$ The Court's fear should be quieted by the practical experience of thirteen states which successfully use the reasonable doubt standard. ${ }^{88}$

There appears to be no sound reason why Chief Justice Bird's analysis and conclusions should not be endorsed. Roulet thus represents an important extention of the Winship-Burnick analysis to involuntary civil commitment proceedings. Yet only three weeks before Roulet was decided, the California Supreme Court in Cramer v. Ty$a^{89}{ }^{89}$ refused to extend the Winship-Burnick analysis to similar issues in involuntary civil commitment proceedings. Moreover, neither the majority nor the dissent in Roulet distinguishes or even inentions the Cramer decision. This puzzling silence raises questions about the analysis the court is endorsing in the area of involuntary civil commitment. $^{90}$

\section{B. Cramer}

In Cramer, the court refused to make available the testimonial privilege to refuse to take the witness stand to a defendant in a proceedimg to commit him for reasons of mental retardation and dangerousness to self and others. Justice Richardson, writing for the majority in Cramer, began by distinguishing two separate testimonial privileges:

In a criminal matter a defendant has an absolute right not to be called as a witness and not to testify. . . . Further, in any proceeding, civil or criminal, a witness has the right to decline to answer questions which may tend to incriminate him in criminal activity. ${ }^{91}$

Justice Richardson held tliat, "The predominantly civil character

87. Id. at $429-30$.

88. Id. at 431 n.5. See also Developments in the Law-Civil Commitment of the Mentally Ill, 87 HARV. L. REV. 1190, 1301 (1974).

89. 23 Cal. 3d 131, 588 P.2d 793, 151 Cal. Rptr. 653 (1979).

90. The failure of Roulet to explicitly recognize Cramer may rest with the politics that goes into reaching a majority consensus. See Goodman and Seaton, The Supreme Court of California 1973-1974. Foreword: Ripe for Decision, Internal Workings and Current Concerns of the California Supreme Court, 62 CALIF. L. REv. 309, 312-18 (1974); Johnson, The Supreme Court of California 1975-1976, Foreword: The Accidental Decision and How It Happens, 65 CALIF. L. REv. 231 (1977).

91. 23 Cal. 3d at 137, 588 P.2d at 796, 151 Cal. Rptr. at 656. 
of the proceedings . . . establishes that appellant did not have an absolute right, as does a defendant in a criminal action, not to be called as a witness and not to testify." 92 He based his "civil character" view on several features of the applicable statutes. He noted that the proceedings need not follow or be related to a criminal conviction; the commitinent is only for one year, and a petition for renewal is subject to the same procedures as the original commitment; and the initiator of the petition need not be a public prosecutor. Additionally, the sole state interest is benevolent care and treatment, not punitive incarceration. ${ }^{93}$

In reviewing the applicable statutes, Justice Richardson described the least criminal-like set of circuinstances under whicl1 a person could be committed. His description is filled witl implications of potentially more onerous circunstances: the commitment is not necessarily related to criminal acts, the petitioner need not be a public prosecutor, and the confinement may be of limited duration but can be renewed. His assessment of the necessary level of protection is based on these least onerous circumstances. However, the breadth of protection afforded should cover the greatest, not the least, threat to the individual. ${ }^{94}$

It is apparent from his language that Justice Ricliardson used the civil/criminal label approach to arrive at his conclusions. ${ }^{95}$ Although he noted the actual consequences which follow commitınent, he did not focus his analysis on those consequences. Rather, lie asserted that the benevolent purposes and "civil" cliaracteristics of the statute distin-

92. Id. at 137, 588 P.2d at 796-97, 151 Cal. Rptr. at 657 (citations omitted).

93. The sole state interest, legislatively expressed, is the custodial care, diagnosis, treatment, and protection of persons who are unable to take care of themselves and who for their own well being and the safety of others cannot be left adrift im the community. The commitment may not reasonably be deemed punishment either in its design or purpose. It is not analogous to criminal proceedings.

Id. at 137, 588 P.2d at 796, 151 Cal. Rptr. at 656-57.

94. In Gault the Supreme Court held that "the availability of the privilege turns . . . upon the nature of the statement or admission and the exposure which it invites." 387 U.S. 1, 49 (einphasis added). Imphicitly, the Court meant the maximum, not the minimun, exposure threatened. Both Gault and Winship tied the protections they afforded juveniles to the maximum threat, the possibility of criminal-like sanctions.

The conclusions Justice Richardson derives froun his description of the commitment process are particularly unconvincing given the facts of Cramer. In Cramer part of the proof of mental retardation was the defendant's violent and criminal behavior. The petitioner in Cramer was the District Attorney, a public prosecutor. As for the limited duration of confinement, the defendant had already been residing at Patton Hospital since 1971. And given his "severe and irreversable mental retardation," it was quite likely that his commitment would last the rest of his life.

95. Justice Richardson stated that "[s]everal features of the applicable statutes ( $\$$ 6500-6512) persuade us that commitment of inentally retarded persons must be deemed essentially civil in nature." $23 \mathrm{Cal}$. $3 \mathrm{~d}$ at $137,588 \mathrm{P.2d}$ at 796, 151 Cal. Rptr. at 656. And it is the "predominantly civil character of the proceedings created by sections 6500-6512 [which] establishes that appellant did not have an absolute right . . . not to be called as a witness and not to testify." Id. at 137, 588 P.2d at 796-97, 151 Cal. Rptr. at 657 (emphasis added). 
guish it from criminal proceedings. ${ }^{96}$

\section{IV}

\section{The Conflict in the Reasoning of Roulet AND CRAMER}

The reasoning underlying the decisions in Roulet and Cramer are in direct conflict. Roulet represents an unequivocal rejection of the "civil" label as a basis for denying traditional criminal constitutional safeguards to a nominally civil defendant facing a serious loss of liberty and imjury to reputation. Cramer, on the other hand, embraces the civil/criminal distinction, and makes the "civil character" of the proceedings the basis for denying the defendant the privilege not to be a witness at proceedings to have him committed as mentally retarded.

The "actual consequences" analysis developed in Winship and Burnick, and extended im Roulet, seems to apply equally to Cramer. Like Roulet, Cramer faced the possibility of substantial loss of liberty and imjury to reputation. Under the Winship-Burnick analysis, the similarity in consequences suggests that the Cramer proceedings should incorporate safeguards similar to those used in Roulet. The proper question, therefore, is whether there is something in the nature of the testimonial privilege which makes it an inappropriate safeguard for $\mathrm{m}$ voluntary commitment proceedimgs. However, an examination of the purposes of the privilege will show that in civil commitment proceedings the privilege is not mappropriate.

Initially, one should note that in juvenile proceedings, the United States Supreme Court in Gault and Winship accorded similar analysis and treatment to the testimonial privilege and the standard of proof. ${ }^{97}$ Although there is no punitive purpose to civil commitment proceedimgs, the courts should still link the two safeguards together.

By allowing the defendant the right not to be called as a witness,

96. One need look no further than the Welfare and Institutions Code to see that the same features apply in grave disability proceedings. The grave disability proceedings need not be related to any criminal acts; the confinement is limited to one year, and a petition to extend the confinement is subject to the same procedures as the original petition $(\$ \S 5358,5361)$; the initiator of the petition need not be a public prosecutor ( $\$ \S 5352,5352.5)$; and the state's purpose is treatment, supervision, and placement $(\$ 5350.1$ ). The Roulet opinion does not infer any civil character from these features of sections 5350-5361. Rather, in the face of these sections the majority lield traditional civil protections madequate.

The juxtaposition extends beyond the opinions' specific statutory bases to their very approach. Cramer speaks of the "civil character" of the proceedings, and of the non-availability of "criminal" protections. Roulet, quite to the contrary, regards the distimction as one of "mere labels." The Roulet majority refused to take "false coinfort in the fact that appellant's commitment is only a "civil' confinement for remedial purposes." 23 Cal. 3d at 224, 590 P.2d at 4, 152 Cal. Rptr. at 428.

97. See 387 U.S. 1; 397 U.S. 358. 
the testimonial privilege keeps the criminal defendant from mistakenly waiving his right not to incriminate himself. This idea also applies to involuntary commitment proceedings. The subject of the commitment proceedings nuay mistakenly make statements which result in his losmg his liberty and injuring his reputation.

The modern view of the privilege also mcludes the notion that even guilty persons are to be treated with basic respect for their human dignity. This respect demands that those persons not be compelled beyond a poimt to participate in estabhishing their own guilt. ${ }^{98}$ Such respect for human dignity certainly must extend to the mentally and emotionally ill.

One result of applying the testimonial privilege, either $\mathrm{m}$ criminal cases or in involuntary commitnient cases, is that the testimony of the defendant is entirely excluded froin evidence. Crimmal cases differ from involuntary commitment cases in that the former largely involve the commission of a proscribed act, while the latter deal almost exclusively witl the state of mind of the defendant. The majority in Cramer argued that because civil commitment proceedings largely involve the state of mind of the defendant, it is especially appropriate to require the individual to testify before the jury. ${ }^{99}$

But the subjective nature of commitment proceedings is insufficient reason to disallow the benefits of the testimonial privilege. By denymg the privilege, the state benefits by having the defendant's nonincriminatimg testimony. But as a result, the defendant is denied the vital right not to be compelled to aid in his own mcarceration. Of course, sliould the defendant believe that his testimony would aid his case, he can always choose voluntarily to testify. This balance between the state's interest and the individual's interest suggests that the individual should be compelled to testify only if the testimony is absolutely necessary in order for the jury to reach a verdict.

However, the defendant's testimony is not absolutely necessary. Because long-term involuntary commitment should only be used when the mdividual is truly and seriously ill, neither the testimony of the defendant nor proof less than beyond a reasonable doubt should be needed for the determination. If the subject of the cominitment proceedimgs cannot be found sufficiently ill unless his testimony is compelled and the jury uses proof less than beyond a reasonable doubt, then he may not be so ill that the drastic measure of a minimum one year commitment is needed. Other forms of commitment, lasting for sliorter durations and requiring lesser protections, are always available

98. See C. McCorMICK, LAW OF EvidenCE 798-99 (2d ed. 1972).

99. 23 Cal. $3 d$ at 139,588 P.2d at 798,151 Cal. Rptr. at 658. 
for the less than very seriously ill. ${ }^{100}$

In the abstract, the conflicting reasoning of Roulet and Cramer may represent a curious judicial anomaly. But im the real world of trial courts, this conflict in reasoning inay create confusion and inequity. A judge presiding over a traditionally civil trial, but one in which the defendant faces a possible loss of liberty and injury to reputation, will be uncertain of the scope of constitutional protection to afford the defendant. The judge may look to the nature of the consequences, the nature of the proceedings, and/or the nature of the protection. The reasoning of Roulet suggests that the judge should look to the consequences, and that those consequences mandate the use of the saine protections as those provided a criminal defendant. The reasoning of Cramer, however, suggests that the judge should look to the civil nature of the proceeding, and afford the defendant only the usual civil safeguards. Because Cramer was not distmguished from Roulet on the basis of the safeguard sought, the judge will be uncertam of the weight to attach to the nature of the protection itself.

The potential harm is twofold. First, as between different civil defendants, both of whom face the same potential consequences, one may be afforded greater protections than the other. This inequity would result from different trial judges' interpretations of the two opinions. The result will be uneven application of that part of our civil justice system that results in criminal-like sanctions. Second, in situations where the very liberty of an individual is at stake, the scope of constitutional protection provided inay be inadequate to protect the interests threatened.

For some nominally civil groups facing criminal-like sanctions, such as juvenile delinquents, the scope of constitutional protection has already been largely delineated. For these persons the Roulet/Cramer conflict may not prove detrimental. But for other persons-such as the mentally and emotionally ill, the developinentally disabled, and the infirm elderly - this conflict may lead to harsh results.

The constitutional rights of these persons and others who may be the subject of civil commitment proceedings are still evolving. The California Suprene Court must clarify, not confuse, the scope of constitutional protection which society is prepared to afford these persons. Thus, the court should send a clear message to the lower courts as to the remaming viability or non-viability of civil labels as a means of determining the scope of constitutional protections to be afforded defendants in involuntary civil commitment proceedings.

100. See note 80 and accompanying text supra. 


\section{CONCLUSION}

The California Supreme Court should overrule Cramer. The court should evaluate the testimomal privilege in involuntary commitment proceedings in the same maimer as it evaluated the reasonable doubt standard in such proceedings. The court should recognize that individuals who are the subject of mental retardation proceedings face a serious loss of hiberty of at least one year, and face the stigma of being labelled mentally retarded. These consequences trigger the use of the testimonial privilege in criminal trials and in certam civil proceedings. The threat faced by defendants im mental retardation hearings cannot be distmguished from those facimg juveniles, MDSO's, or crimmals. While there is a benevolent purpose to mental retardation commitment, this purpose does not lessen the threat to hiberty and reputation.

If the court is unwilling to overrule Cramer, then it must distmguish the reasoning of Cramer from that of Roulet. The statutory underpinning and traditional civil character of the proceedings im both Cramer and Roulet are the same; therefore, they do not provide a basis for distinguishing the cases. If the real distmction hes in some relevant difference between the standard of proof and the testimonial privilege, then the court must state this exphcitly. At the saine time, the court must explain why the extension of so many other safeguards to involuntary commitment is apphicable, while the extension of the testimomal privilege is not.

By exphcitly stating its reasoning, the court will provide the lower courts with a basis for determining the scope of constitutional protection to afford defendants in other involuntary commitment proceedings. The court will also be providing the basis for a reasoned debate on the merits of its reasoning.

Lawrence M. Kopeikin*

* B.A. 1976, University of California, Santa Barbara; J.D. 1980, Boalt Hall School of Law, University of California, Berkeley. 
People v. Privitera.' The supreme court upheld conviction of five traffickers in laetrile for having violated section 1707.1 of the Health and Safety Code. In so doing, the court held that neither the federal nor the state constitutional right of privacy protects sale, prescription, or other distribution of an unapproved drug like laetrile. Thus, the applicable standard of review was whether the statute bore a rational relation to achievement of the state interest in the health and safety of its citizens.

The defendants, a physician and four others, were convicted of supplying and distributing laetrile ${ }^{2}$ in violation of the statute. ${ }^{3}$ On appeal, the defendants challenged the constitutionahty of the statute. They claimed that by limiting their patients' access to a particular medical treatment the statute mterfered with patients' constitutional right of privacy and that regardless of government determination of laetrile's ineffectiveness, patients have a "fundannental interest" in access to it. Therefore, they claimed, prosecution of a patient's supplier, whether a physician or not, burdens patient access and infringes the patient's fundamental interest. Finally, defendants urged that such infringeinent is constitutionally permissible only to the extent necessary to achieve a compelling state interest.

The court held that the federal constitutional right of privacy did

1. 23 Cal. 3d 697, 591 P.2d 919, 153 Cal. Rptr. 431 (1979) (Clark, J.) (5-2 decision).

2. Laetrile, a by-product of apricot pits, has been the focus of a public controversy concerning its effectiveness in cancer treatinent. Proponents' medical claims for laetrile range all the way from mere nutritional aid to cancer cure. See, e.g., Comment, Laetrile: Statutory and Constitutional Limitations on the Regulation of Ineffective Drugs, 127 U. PA. L. REv. 233, 233 n.5 (1978). Opponents, including the American Cancer Association, argue that there is no scientific evidence that the drug has any effect whatsoever. Laetrile is generally regarded as nontoxic and non-habitforming. 23 Cal. 3d at 714, 591 P.2d at 929, 153 Cal. Rptr. at 441 (Bird, C.J., dissenting). The Food and Drug Admimistration has banned the distribution of laetrile in interstate commerce. 42 Fed. Reg. 39,768 (1977).

3. Section 1707.1 provides:

The sale, offering for sale, dehivering, giving away, prescribing or administering of any drug, medicie, coinpound or device to be used in the diagnosis, treatment, alleviation or cure of cancer is unlawful and prohibited unless (1) an application with respect thereto has been approved under Section 505 of the Federal Food, Drug and Cosmetic Act, or (2) there lias been approved an application filed with the board setting forth: [ๆ] (a) Full reports of investigations which haye been made to show whether or not such drug, medicine, compound or device is safe for such use, and whether such drug, medicine, compound or device is effective in such use; [†] (b) A full list of the articles used as components of such drug, medicine, compound or device; [१] (c) A full statement of the coinposition of such drug, medicine, compound or device; (d) A full description of the methods used $\mathrm{m}$, and the facilities and controls used for, the inanufacture, processing and packing of such drug, medicine or compound or in the case of a device, a full statement of its composition, properties and construction and the principle or principles of its operation; [1] (e) Such samples of such drug, medicine, compound or device and of the articles used as components of the drug, medicime, compound or device as the board may require; and ["] (f) Specimens of the labeling and advertising proposed to be used for such drug, unedicine, compound or device.

Cal. Health \& SAFETy CODE $\$ 1707.1$ (West 1979). 
not include a right to use unapproved drugs for cancer treatment. A patient's desire to use these drugs is merely an "interest in independence in making certain kinds of important decisions." Although a limited number of such decisions have been recognized by the United States Supreme Court as falling within the right of privacy, medical treatment is not one of them. ${ }^{5}$ Moreover, the Court has long recognized the state's police power to regulate prescription of drugs. ${ }^{6}$ Since the regulation does not affect a fundamental interest, the challenged section is vahid if a rational basis exists for the restriction.

The court pointed out that section 1707.1 is based on legislative findings that the restriction of the distribution of unapproved cancer drugs is required lest cancer patients forego other, possibly effective treatments and squander personal and family funds in the effort. ${ }^{7}$ The court concluded that those are legitimate state interests as to which the statute bears a rational relation.

The court also rejected defendants' claim that the regulation violates the state constitutional right of privacy. ${ }^{8}$ The court reasoned that the provision's primary purpose is protection of citizens from snooping and spying, particularly increased government and business use of electronic surveillance and data collection. ${ }^{9}$ The court found nothing to indicate that the provision concerned protection of "privacy" in the broad sense of autonoiny or freedom from regulation of personal conduct, as opposed to "privacy" in the narrower and more usual sense of freedom from prying into personal conduct.

In dissent, Chief Justice Bird emphasized that the principle underlying the right of privacy is "the right to be left alone-the right to be

4. 23 Cal. 3d at 702, 591 P.2d at 921, 153 Cal. Rptr. at 434; see Whalen v. Roe, 429 U.S. $589,599-600$ (1977).

5. The majority noted that the "important decisions" recognized by the U.S. Supreme Court concern "marriage, procreation, contraception, family relationships, child rearing and education." 23 Ca1. 3d at 702, 591 P.2d at 922, 153 Cal. Rptr. at 434. See, e.g., Roe v. Wade, 410 U.S. 113 (1973) (abortion); Griswold v. Connecticut, 381 U.S. 479 (1965) (contraception); Skinner v. Oklahoma, 316 U.S. 535 (1942) (procreation); Meyer v. Nebraska, 262 U.S. 390 (1923) (child rearing and education).

6. 23 Cal. 3d at 705, 591 P.2d at 923, 153 Cal. Rptr. at 435 (citing U.S. Supreme Court decisions upholding state regulation of drugs by the health professions).

In United States v. Rutherford, 442 U.S. 544 (1979), decided after Privitera, the U.S. Supreme Court upheld the Federal Food, Drug and Cosinetic Act's prohibition of interstate distribution of unapproved drugs, imcluding laetrile. Terminally ill cancer patients challenged the prohibition, claiming that laetrile was exempt from the pre-market approval requirement, that the "safe and effective" requirement was not intended to apply to drugs for the terminally ill, and that the prohibition on distribution interfered with the right of privacy. The Supreme Court, in ruling unanimously that the safety and effectiveness requirements were fully applicable to drugs administered to the terminally ill, did not discuss the constitutional issue.

7. 23 Cal. $3 d$ at 705-06, 591 P.2d at 923-24, 153 Cal. Rptr. at 435-36.

8. CaL. Const. art. I, § 1 .

9. $23 \mathrm{Cal}$. 3d at 709,591 P.2d at 926, 153 Cal. Rptr. at 438. 
free in the private sphere." ${ }^{\text {10 }}$ She concluded that that principle encompassed a right to be left alone in one's use of unapproved drugs for medical treatment. She also argued that a physician has a separate constitutional right to employ unorthodox methods in treating an informed consenting patient. ${ }^{11}$ As a fundamental right those methods can only be restricted in order to achieve a compelling state interest. She finally claimed that the statute was not even rationally related to the legislative purpose of preventing quackery and fraudulent peddling of placebos and "miracle cures." 12

Privitera could not, of course, resolve the ongoing political ${ }^{13}$ and scientific $^{14}$ controversies over laetrile. Moreover, the court did not have to reach, and lience did not resolve, many of the difficult legal questions associated with an autonomy challenge to paternahstic prohibitions. For example, it is unclear whether the finding of a fundamental interest in using or possessing a substance necessarily implies a complementary right of access to $\mathrm{it}^{15}$ or whether a state may ever ban absolutely a per se harmless substance when it lias the alternatives of providing for consumer information about the substance or restricting it to those who have first sought substitute treatment. ${ }^{16}$

Privitera does represent an attempt by the court to develop a con-

10. Id. at $729,591 \mathrm{P} .2 \mathrm{~d}$ at $938-39,153 \mathrm{Cal}$. Rptr. at 450 (Bird, C.J., dissenting). Justice Newman joined Chief Justice Bird's dissenting opinion, except that he would not have relied on the federal constitution. Id. at 740, 591 P.2d at 946, 153 Cal. Rptr. at 458 (Newman, J., dissenting).

11. Id. at 723-25, 591 P.2d at 935-36, 153 Cal. Rptr. at 447-48 (Bird, C.J., dissenting).

12. Id. at 735-39, 591 P.2d at 943-45, 153 Cal. Rptr. at 455-57 (Bird, C.J., dissenting).

13. On February 14, 1980, California State Senator William Campbell introduced a bill to legalize the prescription, sale, and use of laetrile in the state. S.B. 1480, Cal. Legis. Reg. Sess. (1980).

14. See, e.g., Laetrile Evaluation Underway at NCI, 239 J. A.M.A. 19 (1978); 42 Fed. Reg. $39,767,39,786-87$ (1977).

15. Compare Eisenstadt v. Baird, 405 U.S. 438 (1972) (right of unmarried persons to have and use contraceptive devices affords complementary right to one who dispenses such devices to them) with United States v. Reidel, 402 U.S. 351 (1971) (right of recipients to have and use obscene material at hoine-recognized in Stanley v. Georgia, 394 U.S. 351 (1969)-does not afford coinplementary right to one who mails such material to willing recipients).

The majority did not have to reach this "right of access" issue since it found no fundamental interest in use or private possession of laetrile. The dissent did not reach it since it would have found an imdependent right of a physician to employ disapproved treatments.

16. The legislative policy underlying the statute is not avoidance of direct harm from the use of laetrile, but rather avoidance of an "opportunity cost" harm. The laetrile user suffers the possible harms of earlier death from the exclusive use of an ineffective drug and waste of money on a useless treatment.

Those possible harms do not, however, support an absolute ban on laetrile if there is a fundamental interest in the use of such drugs. The state has no compelling interest in banning absolutely a per se harmless substance when it has available such less onerous alternatives as consumer education and requirement of concurrent use of conventional treatments. But see Comment, supra note 2, at 268-71. 
stitutional definition of privacy. ${ }^{17}$ The court appears to be unable to accept a concept of privacy which could be used to protect a wide and varied range of conduct. The California court was unwilling to read broadly United States Supreme Court privacy decisions in order to find a general autonoiny principle supporting defendants' view that privacy protects an individual's choice of medical treatment from government interference. ${ }^{18}$ The court likewise endorsed a narrow interpretation of the state constitution's express right of privacy. By focusing on its "primary purpose" to protect the individual from intrusions by modern surveillance and data collection activities, the court declined an invitation to expand the right of privacy to encompass "an enorunously broad and diverse field of personal action and belief. . . ."19

The inajority's opinion thus suggests that the primary purpose of the state constitutional guarantee, that is, to guard against surveillance and data collection, is its sole purpose. If it is not, ${ }^{20}$ if, rather, the state constitution now protects soine types of personal conduct themselves, then the supreine court should atteinpt to elaborate the contours of such protected personal conduct as soon as a fit case pernits.

Salas v. Cortez. ${ }^{1}$ The supreme court held that the due process clauses of the United States and California Constitutions ${ }^{2}$ require the

17. The right of privacy has been variously defined. See, e.g., Comment, A Taxonomy of Privacy: Repose, Sanctuary and Intimate Decision, 64 CALIF. L. Rev. 1447 (1976) (suggesting a division of privacy claims into three categories: freedom from nuisances and disturbing intrusions; freedom from outside efforts to see or know; and freedom from regulation of the most intimate life choices).

The U.S. Supreme Court's attempt to produce a constitutional definition of privacy has evoked criticism. See, e.g., Ely, The Wages of Crying Wolf: A Comment on Roe v. Wade, 82 YALE L.J. 920 (1973).

18. The court examined Whalen v. Roe, 429 U.S. 589 (1977), Plamed Parenthood v. Danforth, 428 U.S. 52 (1976), and Roe v. Wade, 410 U.S. 113 (1973).

19. White v. Davis, 13 Cal. 3d 757, 774, 533 P.2d 222, 233, 120 Cal. Rptr. 94, 105 (1975) (dictum) (held that covert police intelligence gathering activities at a state university violated state constitutional right of privacy).

20. See National Org. for Reforin of Marijuana Laws v. Gain, 100 Cal. App. 3d 586, 592, 161 Cal. Rptr. 181, 184 (1st Dist. 1979) (Privitera does not purport to constrain the application of the right of privacy only to surveillance and data collection cases). See also Ravin v. State, 537 P.2d 494 (Alaska 1975) (findimg constitutional right under Alaska constitution to possess marijuana at home).

1. 24 Cal. 3d 22, 593 P.2d 226, 154 Cal. Rptr. 529 (1979) (Bird, C.J.) (4-3 decision).

2. The court based its holding on the due process clauses of both the fourteenth amendment to the U.S. Constitution and article 1, \& 7(a) of the California Constitution. See id. at 26, 593 P.2d at 229, 154 Cal. Rptr. at 532. The California Supreme Court held that the U.S. Supreme Court's 
appointınent of counsel for indigent defendants in state-initiated paternity suits. ${ }^{3}$

Appellants Cortez and Castellanos were sued by the Ventura County District Attorney to establish their paternity of two illegitimate children receiving Aid to Families with Dependent Children (AFDC) benefits and to obtain child support. ${ }^{4}$ Appellants both answered in propia persona and unsuccessfully requested court-appointed counsel on the basis of indigency. ${ }^{5}$ Neither responded to the district attorney's interrogatories and requests for information, and neither appeared for trial. The superior court entered default judginents against each.

In reversing the lower court, the supreine court reasoned froin the premise that indigent defendants in certain civil proceedings are entitled to appointed counsel "[w]here the deprivation the defendant faces is significant and the facts are coinplex." It then proceeded to balance the appellants' interest in having counsel appointed against the state's interest in denying such counsel, stating that the appellants' right to appointed counsel inust turn on "the interests involved and the nature of the proceedings."

The court began its balancing by finding the appellants' interest in avoiding an incorrect finding of fatherhood compelling: ${ }^{8}$ a paternity judgment would obligate appellants to support and educate the chil-

recent limitation on the right of criminal defendants to appointed counsel under the sixth annendment, see Scott v. Illinois, 440 U.S. 367 (1979) (no right to appointed counsel for misdemeanor defendants not actually imprisoned), did not preclude a general right to appointed counsel under the fourteenth amendment. $24 \mathrm{Cal} .3 \mathrm{~d}$ at 27 n.2, 593 P.2d at 229 n.2, 154 Cal. Rptr. at 532 n.2. Furthermore, the court's use of the California Constitution as an independent basis according this right to counsel makes the ultimate meaning of Scott irrelevant to the analysis.

3. $24 \mathrm{Cal} .3 \mathrm{~d}$ at $34,593 \mathrm{P} .2 \mathrm{~d}$ at $234, \mathrm{I} 54 \mathrm{Cal}$. Rptr. at 537.

4. Both suits were prosecuted at public expense by the local district attorney, who is authorized by statute to enforce support obligations to children born in or out of wedlock. Such suits are mandatory when the custodial parent is receiving public welfare payınents. See Cal. WeLF. \& INST. CODE \& 11475.1 (West Supp. 1978).

The federal government now requires states to adopt plans for enforcing support obligatious to children receiving Aid to Families with Dependent Children (AFDC). See 42 U.S.C. \$§ 651662 (West Supp. 1979). In California, AFDC recipients inust assign any support rights to the county and cooperate in determining the parentage of any illegitimate children. CAL. WELF. \& INST. CODE $§ 11477$ (West Supp. 1978). The district attorney then files a paternity and/or support suit against the putative father. See CAL. Welf. \& INST. CODE $\$ 11475$ (West Supp. 1978).

5. Miguel Cortez was an "unemployed farmworker;" David Castellanos was an "unemployed laborer." Neither could afford the $\$ 500-\$ 1,000$ cost of private defense counsel. Both unsuccessfully sought representation by local legal aid associations. $24 \mathrm{Cal} .3 \mathrm{~d}$ at 25-26, $593 \mathrm{P} .2 \mathrm{~d}$ at 228-29, 154 Cal. Rptr. at 531-32.

6. $24 \mathrm{Cal} .3 \mathrm{~d}$ at 27,593 P.2d at $229,154 \mathrm{Cal}$. Rptr. at 532 . Only two other state supreine courts have held that due process requires appoimted counsel for indigent defendants facing stateinitiated paternity suits: Reynolds v. Kimmons, 569 P.2d 799 (Alaska, 1977); Artibee v. Cheboygan Circuit Judge, 397 Mich. 54, 243 N.W.2d 248 (1976).

7. 24 Cal. 3d at 27, 593 P.2d at 229, 154 Cal. Rptr. at 532.

8. Id. at 28,593 P.2d at 230, 154 Cal. Rptr. at 533 . The court reasoned that since the interest in maintaining a parental relationship had been held to be "compelling," citing In re B.G., 
dren, could damage their careers, families, and reputations, and could give rise to civil contempt and even crimmal penalties.'

It then found that legal counsel was necessary to appellants' defense of the paternity suits. ${ }^{10}$ Neither appellant had sufficient legal skill to respond to discovery requests, initiate his own requests, or procure experts to perforn blood tests. ${ }^{11}$ These deficiencies contributed significantly to the findings of paternity in both cases. ${ }^{12}$ Further, the court found, the state's funding and control of what was traditionally a private suit also threatened to significantly affect the outcome. ${ }^{13}$

Under these circumstances, only a "compellimg" state interest could justify refusing to appoint the counsel necessary for a meaningful defense. ${ }^{14}$ The court found the state's interest in assisting the custodial parent in enforcing the support obligations of the absent parent and in relieving the state of welfare burdens inadequate to justify sucl an imposition on indigent defendants. ${ }^{15}$ It also implicitly rejected the state's mere financial interest in avoiding additional litigation expenses. ${ }^{16} \mathrm{Fi}-$ nally, the court stated that the state's most compelling interest, defined narrowly as the correct determination of parental obligations, would be furthered rather than harmed by appointing counsel, thus adding to the

11 Cal. 3d 679, 688-89, 523 P.2d 244, 250, 114 Cal. Rptr. 444, 450 (1974), the interest in avoiding incorrect imposition of such status must be no less compelling.

9. $24 \mathrm{Cal} .3 \mathrm{~d}$ at 28-29, 593 P.2d at 230-31, $154 \mathrm{Cal}$. Rptr. at 533-34. The court stressed that the paternity determination may have collateral effects on the defendant's liberty. The support obligation may be enforced by civil contempt proceedings, CAL. Civ. CODE \& 7012(c) (West Supp. 1979), in which the paternity judgment would be res judicata, CAL. Civ. CoDE $\$ 7010$ (a) (West Supp. 1979). Moreover, the paternity judgment would be admissible in a subsequent criminal prosecution under CAL. PENAL CODE $\$ 270$ (making willful non-support of a child a misdemeanor punishable by fine and/or imprisonment). Cal. PEnal COdE $\$ 270$ e (West Supp. 1979).

10. 24 Cal. $3 d$ at 30-31, 593 P.2d at 232, 154 Cal. Rptr. at 535.

11. 24 Cal. $3 d$ at 30 \& n.6, 593 P.2d at 232 \& n.6, 154 Cal. Rptr. at 535 \& n.6.

12. The appellants were adjudged fathers solely on the basis of "(1) alleged facts which were deemed admitted because not contradicted, and (2) testimony of the mother which was not subjected to cross-examination." Id. at 31, 593 P.2d at 232, 154 Cal. Rptr. at 535.

13. Id. The fact-finding process may be corrupted by state intervention long before the case reaches court. In order to receive benefits, an AFDC recipient must name the father of any illegitimate child for whom benefits are claimed. The risks are great that the wrong man will be nained under suclt compulsion if the inother does not know who the real father is, wishes to protect the real father, or fears retribution to herself or her child. Id. at $31 \mathrm{n} .7,593 \mathrm{P} .2 \mathrm{~d}$ at $232 \mathrm{n.7}, 154 \mathrm{Cal}$. Rptr. at 535 n.7.

The risks of imcorrect identification and the benefits of legal counsel for paternity defendants are illustrated by the Castellanos case. The district attorney had first sued another man as the father of the child involved. When this "father" retained counsel and successfully opposed the suit, the district attorney then sued Castellanos. When Castellanos was unable to secure counsel and failed to attend the temporary support liearing, a default judgment of paternity ensued. Id. at 31 n.8, 593 P.2d at 232 n.8, 154 Cal. Rptr. at $535 \mathrm{n} .8$.

14. Id. at 32, 593 P.2d at 233, 154 Cal. Rptr. at 536.

15. See id. at 32-33, 593 P.2d at 233, 154 Cal. Rptr. at 536.

16. Id. at 33, 593 P.2d at 233, 154 Cal. Rptr. at 536. 
integrity of the fact finding process. ${ }^{17}$

Justice Richardson dissented, contending that appellants' interest in defending the paternity suit was solely financial and therefore indistinguishable from the interest of any civil litigant. ${ }^{18}$ Due process, according to Richardson, requires only access to the courts for indigent civil litigants who seek to vindicate inere financial interests. ${ }^{19} \mathrm{He}$ argued further that the majority's analysis could be readily extended to other situations, thus imposing an unsound and intolerable "new fiscal obligation on the public taxpayer."20

Salas v. Cortez gives practical effect to constitutional due process guarantees. The recognition that a "meaningful opportunity to be heard" may be available to mdigent civil defendants only when the court appoints counsel is long overdue. Admittedly, the court's holding requires such counsel only in state-initiated paternity suits. The nature of the interests and proceedings involved, lowever, suggest that the court's analysis may not be so limited. It may well require appointed counsel in otler situations in which "compelling" or "significant" interests-"merely financial" or otherwise-are threatened and in which the court's fact finding nuay be corrupted by an imbalance of litigation resources. Interests other than the avoidance of parental obligations may also be sufficiently compelling under the circumstances; ${ }^{21}$ lack of counsel inay seriously distort the fact finding process even wlien the state is not a party to the litigation. The court's test thus appears to require a close examination of the immediate and potential consequences of lack of counsel to an indigent defendant in each type of case. As a consequence, Salas implicitly recognizes that appointed counsel may be necessary in a variety of possible civil cases.

17. Id. at 33, 593 P.2d at 233-34, 154 Cal. Rptr. at 536-37. Although the court did not consider the interests of the custodial parent, it contended that the interests of the child, again narrowly defined as a correct determination of parentage, would also be served by appointed counsel. "When the state initiates paternity proceedings, . . . the state owes it to the child to ensure that an accurate determination of parentage will be inade." Id. at 34, 593 P.2d at 234, 154 Cal. Rptr. at 537.

18. Id. at 36, 593 P.2d at 235, 154 Cal. Rptr. at 538 (Richardson, J., dissenting).

19. See id. at 39-40, 593 P.2d at 238, 154 Cal. Rptr. at 541 (Richardson, J., dissenting).

20. Id. at 37, 593 P.2d at 236, 154 Cal. Rptr. at 539 (Richardson, J., dissenting). Even if limited to state-initiated paternity suits, the majority's holding, according to Justice Richardson, results in an undue burden on the public fisc. He pointed out that the majority had not ruled on whether the defense of indigent paternity defendants was to be undertaken by the bar as a pro bono responsibility or by state-funded attorneys, but implied that the latter would eventually be required. He also speculated that the majority's analysis may require a public subsidy of the indigent paternity defendant's costs for discovery and expert witnesses. Id. at 42, 593 P.2d at 239, 154 Cal. Rptr. at 542 (Richardson, J., dissenting).

21. For example, a welfare recipient may have a "compelling" interest in defending a state suit to recover back benefits allegedly obtamed by fraud. For those at the margin of subsistence, even "mere" financial considerations may be compelling. 
Bondanza v. Penisula Hospital \& Medical Center.' The court held that a hospital's practice of assessing patients a collection charge consisting of one-third of the total bill for medical services was an unlawful or unfair business practice within the ineaning of section 17200 of the California Business \& Professions Code $^{2}$ and sections 1670 and 1671 of the California Civil Code. ${ }^{3}$

There were three plaintiffs, each of whoin, on admission to defendant hospital, signed an agreeinent to pay his or her hospital fees and any "reasonable attorney's fees and collection expenses" incurred if the account were referred to a collection agency or an attorney for collection. ${ }^{4}$ Each plaintiff failed to pay his or her bill on time. After trying to collect the bills for approximately six months, the hospital assigned plaintiffs' accounts to a collection agency whose collection fee was onethird of the amount referred. Shortly after the assigninent, plaintiff Bondanza's insurer paid all but $\$ 67.00$ of her bill. The collection agency subsequently deinanded payinent of $\$ 242.80$ : $\$ 67.00$ due on the bill and $\$ 175.80$ in collection costs (one-third of the balance due on the date of assignment, plus interest). The other plaintiffs had similar experiences.

Bondanza paid only the $\$ 67.00$ and sued the hospital for, inter alia, declaratory and injunctive rehef, alleging that the collection fee was an unlawful and unfair business practice. The trial court denied plaintiff's motion to certify the suit as a class action and granted defendant's motion for summary judgment. It did, however, enjoin the hospital fron assessing any collection charges agamst the named plaintiffs. ${ }^{5}$

The supreme court reversed and granted imjunctive relief, stating that the collection charge was "plainly unlawful." The court considered the collection provision an illegal liquidated damages clause be-

1. 23 Cal. 3d 260, 590 P.2d 22, 152 Cal. Rptr. 446 (1979) (Mosk, J.) (4-3 decision).

2. Cal. Bus. \& Prof. Code $\S 17200$ (West Supp. 1979).

3. The substance of both statutes is now consolidated in $\S 1671$, which provides that in specific cases:

(d) [A] provision in a contract hiquidating damages for the breach of the contract is void except that the parties to such a contract may agree therein upon an amount which shall be presumed to be the amount of danage sustamed by a breacl thereof, when, from the nature of the case, it would be impracticable or extremely difficult to fix the actual dainage.

Cal. Civ. Code $\$ 1671$ (West Supp. 1979).

4. $23 \mathrm{Cal} .3 \mathrm{~d}$ at 263,590 P.2d at 23, 152 Cal. Rptr. at 449.

5. Id. at 265, 590 P.2d at 25, 152 Cal. Rptr. at 449.

6. Id. at 267, 590 P.2d at 26, 152 Cal. Rptr. at 450 . See Garrett v. Coast \& S. Fed. Sav. \& Loan Ass'n, 9 Cal. 3d 731, 511 P.2d 1197, 108 Cal. Rptr. 845 (1973) (imvalidating a penalty charge for the late payment of a loan). 
cause the hospital never attempted to estimate a fair compensation for breach, nor did it attempt to show that it would have been impracticable to fix actual costs. ${ }^{7}$

The court also considered the collection provision unfair. It first described the admission agreement as a contract of adhesion that in1posed a condition over which patients often had no control: they frequently relied on insurers who could delay or refuse to make payments. ${ }^{8}$ The court next noted that the percentage collection charge bore no relation to the actual collection cost, particularly when a patient had paid before the agency had inade sigmificant efforts to collect the debt. ${ }^{9}$ Finally, the court was not persuaded by the fact that the hospital was bound to pay the percentage fee; it cited the "fundamental rule" that a creditor caimot increase a debtor's burden by assigning the debt. ${ }^{10}$ The hospital was limited to the actual costs of collection.

Justice Manuel argued in dissent that the collection fee provision was not a liquidated damages clause, because it neither set the annount of damages nor devised a method for determining such an amount in anticipation of breach. ${ }^{11}$ Manuel agreed with the appellate court's finding that the broad injunction was unwarranted: although the fee charged these patients was unreasonable, there was no showing that percentage fees are all unreasonable as a inatter of law. ${ }^{12} \mathrm{He}$ also agreed that any reform of collection agencies' fee setting practices should coine through the existing regulatory framework. ${ }^{13}$

The holding in Bondanza extends the definition of liquidated dainages clauses beyond the language of Busimess \& Professions Code section 17200 and Civil Code sections 1670 and 1671. If one were to read this holding literally, it could result in the prohibition of such coinmonly accepted contract clauses as those allocating the burden of attorney's fees in the event of litigation. Because of this possibility, Bondanza should be considered a narrow holding on the facts, with special attention paid to the court's characterization of the admission agreement as a contract of adhesion.

7. 23 Cal. 3d at 267, 590 P.2d at 26, 152 Cal. Rptr. at 450. CAL. Clv. Code $\S 1671$ (West Supp. 1979) places the burden of demonstratimg such impracticability on the party attempting to enforce a liquidated damages clause. $23 \mathrm{Cal}$. 3d at 267, $590 \mathrm{P} .2 \mathrm{~d}$ at 26, $152 \mathrm{Cal}$. Rptr. at 450 (citing Chastain v. Belmont, 43 Cal. 2d 45, 58, 271 P.2d 498, 506 (1948); Lowe v. Massachusetts Mut. Life Ins. Co., 54 Cal. App. 3d 718, 734, 127 Cal. Rptr. 23, 32 (1st Dist. 1976).

8. 23 Cal. 3d at 267,590 P.2d at 26,152 Cal. Rptr. at 450.

9. Id. 1954)).

10. Id. at 268,590 P.2d at 26,152 Cal. Rptr. at 451 (citing CAL. CIv. CoDE $\S 1459$ (West

11. Id. at 270,590 P.2d at 28, 152 Cal. Rptr. at 452 (Manuel, J., dissenting).

12. Id. at 273,590 P.2d at 30,152 Cal. Rptr. at 454.

13. Id. at 271-72, 590 P.2d at 28-29, 152 Cal. Rptr. at $452-54$. 